\title{
Information System for Doctor Practice Scheduling at Hospitals in Jember District
}

\author{
Mochammad Choirur Roziqin* \\ Health Department \\ Politeknik Negeri Jember \\ Jember, Indonesia \\ irul@polije.ac.id
}

\author{
Dony Setiawan Hendyca Putra \\ Health Department \\ Politeknik Negeri Jember \\ Jember, Indonesia \\ dony_shp@polije.ac.id
}

\author{
Muhammad Syeikhooni Noor \\ Health Department \\ Politeknik Negeri Jember \\ Jember, Indonesia \\ oni.unity@gmail.com
}

\begin{abstract}
Making an apt decision can reduce the impact of a disaster as part of disaster mitigation. Disaster mitigation cannot be separated from hospital services related to doctors and medical teams in providing services to patients. Ideally, choosing a hospital during a disaster case is not only based on the proximity of the distance, but also related to the availability of doctors and the capacity of the hospital in providing services for certain cases to patients. Information from the BPBD mentions that disasters in Jember regency have increased from 2018 to 2020. For example, cases of disasters that have occurred in Jember regency include: drought, typhoons, landslides, and floods. What really grabs the public's attention at this time is the Covid-19. Handling cases of natural disaster patients, medical workers and health workers are required to work quickly and accurately in providing services to patients, and this cannot be separated from referral services to other hospitals whose health services are better prepared to accommodate and handle patients. As a solution for the above problems, the researchers created an information system for scheduling doctors' practices in hospitals that can be accessed by the hospital and BPBD. This research delves into doctor's practice scheduling information system in Jember public hospital based on the current needs of the hospital and BPBD. This research finding can help health services in making patient referrals to the targeted hospital quickly and on target. It is hoped that the information system will be monitored and evaluated regularly so that it can continue to be developed to meet public needs.
\end{abstract}

Keywords-Electronic Health Record, Disaster Management, Forward Chaining

\section{INTRODUCTION}

Disaster is an event or series of events that threatens and disrupts people's lives and livelihoods which are caused by both natural and non-natural as well as human factors, resulting in human casualties, environmental damage, property loss and psychological impacts. Meanwhile, natural disasters are disasters caused by an event or a series of events caused by nature, among others, in the form of earthquakes, tsunamis, volcanic eruptions, floods, drought, hurricanes and landslides. In today's disaster management, information system is needed to provide fast handling [1].

Information system provides information for management in making decisions and aids also in running company operations. To this point, the system is a combination of society, information technology and organized procedures. In health sector, one example of deploying such system is concerning types of medical services and web-based specialist doctor's service schedules, in which the system is embedded [2]. This application can help the public easily obtain information about health, specialist doctor schedules.

Some of hospitals in Jember district still rely on schedule board (banner/ neon box) in scheduling doctors' working hours. When patient needs to know the doctor's schedule, he can obtain the information by checking the schedule. Hospital service in informing doctor's schedule is not readily available for the public[3]. Health institution shoulders crucial roles in people's life, especially to provide health services when people require health services or health consultation. To obtain health services, a patient usually has to go through several procedures, such as coming to the hospital to register, queuing, and so on, not to mention doctor being unavailable. Such manual scheduling mechanisms is very cumbersome and inefficient.

The information system is highly required for the advancement of hospital services. Information systems are a collection of hardware, software, databases, telecommunications, humans and procedures designed to transform data into useful information [4]. Hospital in Jember serves as a company engaged in the health sector. The number of patients in Jember hospitals is increasing every year. As a corollary, the hospital needs an information system to improve hospital services[5].

Disasters in Jember district have increased from 2018 to 2020. Disaster cases that have occurred in Jember Regency include drought, typhoons and landslides, and floods. What really gains the attention of the wider community at this time is the Covid-19 case. Handling cases of natural disaster patients, medical personnel and health workers are required to work quickly and accurately in providing services to patients. This laborious works require referral services to other hospitals with better services to accommodate and handle patients. To cope with the above problems, the researchers created an information system for scheduling doctors' practices in hospitals that can be accessed by the hospital and BPBD. This research is a research that manages doctor's schedule in Jember hospitals, based on the current needs of the hospital and BPBD. The purpose of this study is to assist health services in making patient referrals to the targeted hospital quickly and accurately. 


\section{METHOD}

In developing the information system, the researchers went through the following stages as presented in Figure 1.

\section{A. Requirement}

At this stage, the system developer had to know all the information about the software requirement, such as the use of the software desired by the user and software limitations. This information was usually obtained from interviews, surveys, or discussions. After that, the information was analyzed to get complete data about the user's needs as the basis for the development.

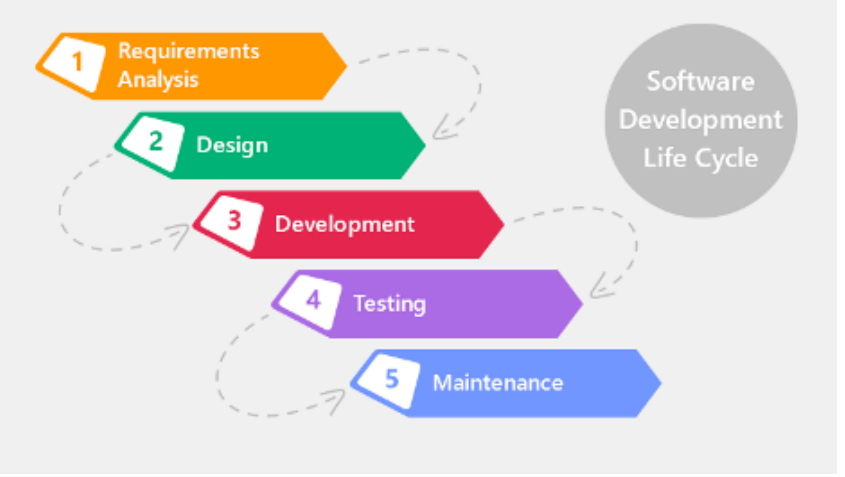

Fig. 1. Stages of information system development

\section{B. Design}

The next stage was Design. The design was done before the coding process began. It aimed to provide a complete picture of what to do and how the desired system looked like. This helped to specify hardware and system requirements, and that defined the system architecture to be made as a whole.

\section{Implementation}

Software coding took place at this stage. The software development was broken down into small modules, which were combined in a later stage. At this stage, there was also a deeper examination of the module design, aimed at ensuring whether it had fulfilled the desired function or not.

\section{Integration and Testing}

At this fourth stage, the previously made modules were merged. After that, a test was carried out to find out whether the software complied with the desired design and to find out any possible error.

\section{E. Operation and Maintenance}

Operation and Maintenance were the last stage of the development scheme. At this stage, the finished software was run or operated by the user. Besides, maintenance was also carried out, which included repairing errors, improving the implementation of system unit, and improving system services according to new needs.

\section{RESULT AND DISCUSSION}

\section{A. Hospital Profile Interface}

The Hospital Profile interface contains some general information associated with the hospital. This involves is the doctor's information at the hospital. On the interface, the doctor displayed is the one who will be or is practicing on particular day. For more detailed information regarding the profile of each doctor or other doctors in the hospital, users can go to the Doctor interface by clicking View Details, next to the Doctor writing as shown above.

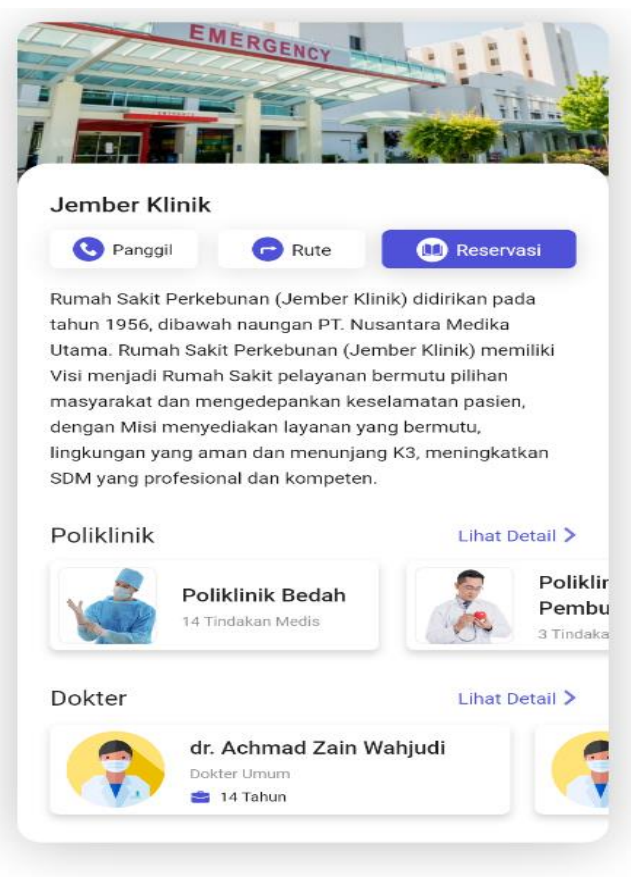

Fig. 2. Hospital Profile interface

\section{B. Doctor Interface}

The Doctor interface contains information related to all doctors in a hospital. The display shown includes the doctor's name, expertise, work experience, and the doctor's practice schedule. At the top of the Doctor interface, there is a submenu that makes it easy to sort the doctors to look for. Below the submenu, there is a search box to perform a search. Next to the search box, there is an additional filter, which is useful to sort doctors who are currently available or will be available at particular time. Also, we can see all doctors from the list.

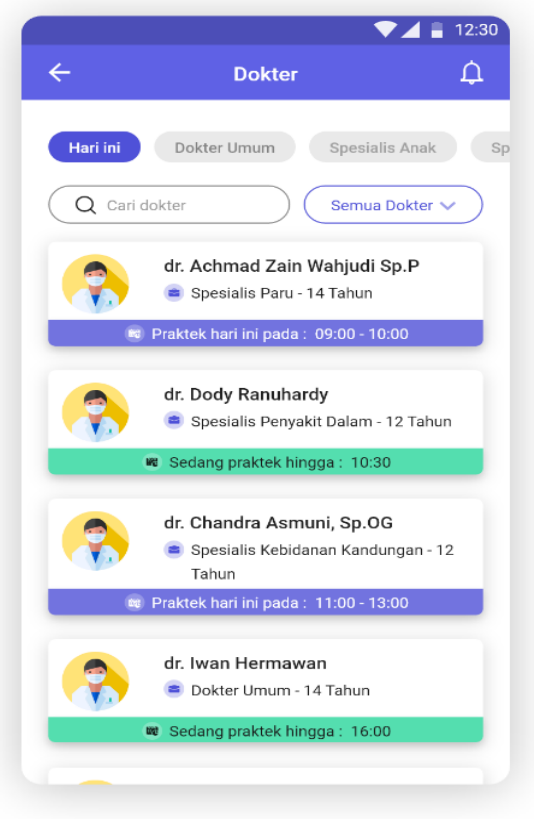

Fig. 3. Doctor interface 


\section{Doctor's Profile Interface}

On the Doctor's Profile interface, the user can obtain details about the doctor. These details are related to name, STR number, expertise, and work experience. There is also a general description of each doctor. At the bottom, there is complete information about the doctor's practice schedule, which can be seen by date. The schedule includes the date, place of practice, and time of practice.

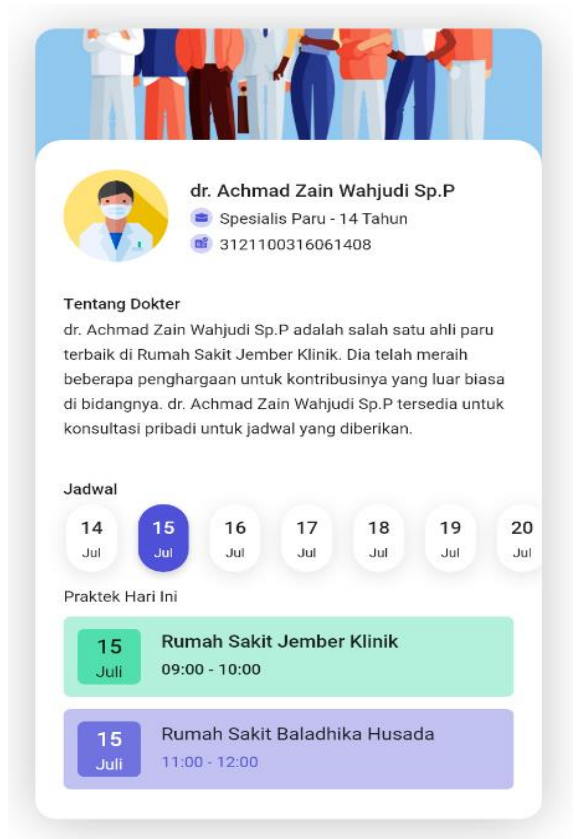

Fig. 4. Doctor's Profile interface

\section{CONCLUSION}

From the results of trials that have been conducted with several respondents. respondents claimed to be comfortable and easy to use this system. a good system is a system that has been tested by many respondents. This system also still needs to be tested on many users in order to become a perfect system. Further evaluation will take place throughout its implementation. The result is projected to provide patients with important details to put them at ease when scheduling doctor appointment.

\section{ACKNOWLEDGMENT}

We would like to express our sincere gratitude to Politeknik Negeri Jember for the research funding through PNBP Scheme in 2020.

\section{REFERENCES}

[1] Undang - Undang Nomor 24 Tahun 2007 Tentang Penanggulangan Bencana Alam.

[2] MC Roziqin, DSH Putra. 2019. Recording Natural Disaster Victim Patients By Using Android-Based In Jember Regency. Proceeding of the International Conference on Food and Agriculture.

[3] Puti Damayanti, Sutono.2017. Faktor-Faktor yang Beresiko Terjadinya Pasien Stagnan di Instalasi Gawat Darurat. Universitas Gadjah Mada

[4] Farlinda, S., Roziqin, M. C., Hikmah, F., \& Pratama, Y. (2020, July). Designing and Creating Web-Based Outpatient Information System At Panti Community Health Center (Puskesmas) Jember. In Journal of Physics: Conference Series (Vol. 1569, No. 2, p. 022012). IOP Publishing.

[5] Joko Trianto.2018. Penerapan Metode Forward Chaining Untuk Diagnosa Penyakit Diare Pada Anak Usia 3-5 Tahun Berbasis Mobile Android. Universitas Pamulang 